\title{
Desflurane why this choice?
}

\author{
Nabil Al Todd \\ From de Senectute: Age and Health Forum \\ Catanzaro, Italy. 5-7 December 2009
}

In considering the future role of the volatile anesthetic desflurane (Suprane ${ }^{\circ}$ ) in modern anesthesia practice, it is important to first consider the factors that contribute to a successful anesthetic in this increasingly day surgery orientation. An optimal anesthetic for the new millennium would include the following characteristics.

1. It should have a rapid and smooth onset of action. Efficiency is a particularly important factor in the ambulatory setting $[1]$

2 . There should be a rapid recovery of cognitive functioning without clinically-significant discomfort. Postoperative pain is a major limiting factor in determining when a patient can be discharged home after surgery.

3. The absence of adverse effects such as nausea and vomiting is extremely important as emetic symptoms affect not only recovery times but also the incidence of unanticipated hospital admissions after day-case surgery, and patient satisfaction with their overall anesthetic experience.

The low solubility of desflurane contributes to rapid emergence after anesthesia. Compared with sevoflurane, recovery times to eye opening, response to verbal commands, and orientation to person, place, and time have been found to be significantly shorter with desflurane [2-4]. When compared with the rapid, short-acting intravenous anesthetic propofol for induction and maintenance of anesthesia, desflurane displayed more favorable early recovery characteristics and facilitated the fast-tracking process $[4,5]$. Although patients receiving desflurane are less sedated in the early postoperative period than those receiving propofol, times to ambulation and discharge were similar.

Given its favorable early recovery profile, desflurane would appear to be a useful alternative to isoflurane, sevoflurane and propofol for maintenance of anesthesia

Medical Affairs Manager Baxter S.p.A., Italy

BHoMed Central @ 2010 Todd; licensee BioMed Central Ltd. in a busy practice environment where early discharge is one of the major goals (e.g., cardiovascular, neurosurgery, day-case surgery).

In conclusion, desflurane is the maintenance anesthetic agent of choice in a fast-tracking practice environment.

Published: 19 May 2010

\section{References}

1. White PF: Ambulatory anesthesia advances into the new millennium. Anesth Analg 2000, 90:1234-5.

2. Ghouri AF, Bodner M, White PF: Recovery profile after desflurane-nitrous oxide. Anesthesiology 1991, 74:419-24.

3. Van Hemelrijck J, Smith I, White PF: Use of desflurane for outpatient anesthesia. Anesthesiology 1991, 75:197-203.

4. Song D, Joshi GP, White PF: Fast-track eligibility after ambulatory anesthesia. Anesth Analg 1998, 86:267-73.

5. Tang J, White PF, Wender RH, Naruse R, Kariger R, Sloninsky A, Karlan MS, Uyeda RY, Karlan SR, Reichman C, Whetstone ORT: Fast-track office-based anesthesia. Anesth Analg 2001, 92:95-9.

doi:10.1186/1471-2318-10-S1-L70

Cite this article as: Al Todd: Desflurane why this choice? BMC Geriatrics 2010 10(Suppl 1):L70.
Submit your next manuscript to BioMed Central and take full advantage of:

- Convenient online submission

- Thorough peer review

- No space constraints or color figure charges

- Immediate publication on acceptance

- Inclusion in PubMed, CAS, Scopus and Google Scholar

- Research which is freely available for redistribution

Submit your manuscript at www.biomedcentral.com/submit
C Biomed Central 